\title{
Behaviors of the Yukon River Sediment Plume in the Bering Sea: Relations to Glacier-Melt Discharge and Sediment Load
}

\author{
Kazuhisa A. Chikita ${ }^{1,}$, Tomoyuki Wada ${ }^{2}$, Isao Kudo ${ }^{3}$, Sei-Ichi Saitoh ${ }^{1}$, Toru Hirawake ${ }^{4}$ and Mitsuhiro Toratani ${ }^{5}$ \\ 1 Arctic Research Center, Hokkaido University, Sapporo, 001-0021 Japan; ssaitoh@arc.hokudai.ac.jp (S.S.) \\ 2 Earth System Science, Co., Ltd., Tokyo 160-0022, Japan; wada-tomoyuki@ess-jpn.co.jp \\ 3 Faculty of Fisheries Science, Hokkaido University, Hakodate, 041-8611 Japan; ikudo@fish.hokudai.ac.jp \\ (I.K.), hirawake@fish.hokudai.ac.jp (T.H.) \\ 4 National Institute of Polar Research, Tokyo, 190-8518, Japan; hirawake.toru@nipr.ac.jp \\ 5 Department of Optical and Imaging Science and Technology, Tokai University, Hiratsuka, 259-1292 Japan; \\ tora@keyaki.cc.u-tokai.ac.jp \\ * Correspondence: chikita@sci.hokudai.ac.jp; Tel.: +81-11-772-4292
}

\begin{abstract}
Sediment plumes, released to the Bering Sea from the delta front of the Yukon River, Alaska, are initiated mainly by glacier-melt sediment runoffs in the glacierized regions of the $\mathrm{Yu}-$ kon River drainage basin. The surface sediment plumes are extended around the fan-shaped $\mathrm{Yu}-$ kon River delta, which is followed by the northwestward dispersion. During continuous measurements of the Yukon River discharge and sediment load, behaviors of the sediment plumes were explored by shipboard observations in the Bering Sea offshore from the Yukon delta. At the high river sediment load of ca. $3000 \mathrm{~kg} / \mathrm{s}$, the plume partially plunged into the sea bottom layer. The plunging probably originated in the nepheloid-layer formation from the flocculation of river-suspended sediment, of which more than $90 \% \mathrm{wt}$. is silt and clay (grain size $\mathrm{d}<0.063 \mathrm{~mm}$ ). In order to numerically obtain the area of the surface sediment plumes, a satellite image analysis was performed by using three near-infrared bands in MODIS/Aqua or MODIS/Terra. The plume area was significantly correlated $\left(R^{2}=0.735, p<0.01\right)$ to the sediment load averaged for the two days with time lags of 20 days and 21 days to the date of a certain satellite image. Hence, the dispersion of plumesuspended sediment appears to be controlled by the sediment runoff events in the Yukon River rather than the northward "Alaskan Coastal Water".
\end{abstract}

Keywords: Yukon River; sediment load; surface sediment plume; density underflow; MODIS image

\section{Introduction}

In the coastal area receiving the river inflow, the river water is mixed with the marine water, accompanied by the dissipation of flow energy. Thereafter, the mixed water (brackish water) departs from the bottom bed to the surface layer, and moves offshore as a slow hypopycnal (buoyant) surface plume (flow speed of the $0.1 \mathrm{~m}$ order) [1]. The liftoff of the mixed water up to the surface layer is based on the fact that the mixed water density $\rho$ (e.g., $\rho=1,001-1,012 \mathrm{~kg} / \mathrm{m}^{3}$ at $25^{\circ} \mathrm{C}$ in temperature and $5-20 \%$ in salinity at water surface) is smaller the marine water density $\left(\sim 1,023 \mathrm{~kg} / \mathrm{m}^{3}\right.$ at $25{ }^{\circ} \mathrm{C}$ and ca. $35 \%$ at water surface). The offshore movement of such a river plume is accompanied by the dispersion or advective diffusion of terrigenous dissolved and suspended matters, of which the adsorption and deposition can be incorporated into the coastal and marine ecosystems including carbon and nutrient cycles $[2,3]$.

When the river is rich in suspended sediment as in the high sediment runoffs by heavy rainfall, snowmelt or glacier-melt, the river sediment plume mostly behaves as a surface sediment plume in the offshore region. This is because the mixed water in the 
coastal region generally has the suspended sediment concentration (SSC) of much less than ca. $5 \mathrm{~g} / \mathrm{L}$, thus being much lighter than the marine water [4,5]. Then, the bulk density $\rho_{\mathrm{t}}\left(\mathrm{kg} \mathrm{m}^{-3}\right)$ of the mixed water at SSC, C $(\mathrm{g} / \mathrm{L})$ is obtained by $\rho_{\mathrm{t}}=\rho(1-\mathrm{C} / \sigma)+\mathrm{C}$, where $\sigma$ is particle density $\left(\mathrm{kg} / \mathrm{m}^{3}\right)$. The density $\sigma$ could vary greatly at $1,030-2,850 \mathrm{~kg} \mathrm{~m}^{-3}$, depending on the content rate of particulate organic matters [6,7].

Behaviors of such a sediment surface plume could be affected by littoral, tidal and wind-driven currents, and hydrological conditions of the river [5,8,9], of which the dynamical influence changes depending on the turbulent level of the currents and the distance from the estuary. For example, by shipboard observations and satellite images of surface water temperature for the MacKenzie River plumes in the Arctic Ocean (MacKenzie River discharge, $9.8 \times 10^{3} \mathrm{~m}^{3} / \mathrm{s}$ as annual mean), Mulligan et al. [10] showed that the offshore movement of the river plume and the onshore transport of the deeper shelf water are strongly affected by wind-driven currents at 5-10 m/s wind. With respect to the Amazon River $\left(2.0 \times 10^{5} \mathrm{~m}^{3} / \mathrm{s}\right.$ as annual mean), applying the 16-yr data of satellite images and river discharge to the Amazon River plumes, Gouveia et al. [11] pointed out that a positive precipitation trend in the western Amazon basin makes the river plumes decrease the ocean salinity on the pathway by increasing the river discharge.

For river plumes of the small scale with river discharge of $10 \mathrm{~m}^{3} / \mathrm{s}$ order or less, the effects of tidal and wind-driven currents on the plumes' dispersion are relatively strengthened. For example, by the vertical profiling of water quality on the ship and numerical simulation, Masunaga et al. [12] showed that the mixing of the river plume initiated by river discharge of $3-35 \mathrm{~m}^{3} / \mathrm{s}$ is dominated by the wind stress and baroclinic tidal flow.

Focusing on sedimentation in the coastal and offshore zones under the influence of river inflow, behaviors of suspended sediment in the mixing zone with decaying flow energy and increasing salinity, and in the offshore zone, accompanied by the surface sediment plume and associated currents, are important to know the sedimentary processes. In the mixing zone, of which the bottom is often gently sloped, the flocculation (or aggregation) of suspended sediment tends to prevail and consequently produce a nepheloid (suspended-sediment rich) layer near the bottom, which could shift to density underflow moving downslope more offshore [13]. The flocculation process of suspended sediment has been explored by field observations, laboratory experiment and numerical models [14-17]. However, the connection of the flocculation process to the subsequent nepheloid layer behaviors is not well known $[18,19]$. It is because growing the first thin nepheloid layer up to the one thick enough to produce the density underflow on the slope is very difficult in the laboratory experiment and numerical simulation.

An objective of this study is to investigate how the river sediment plume dynamically behaves and is dispersed in the coastal and offshore regions, being exemplified by the Yukon River sediment plume. In this paper, the formation of the nepheloid layer ascertained by the outboard observations in the coastal region is connected to offshore behaviors and associated sedimentary process of the Yukon sediment plume obtained by shipboard observations and satellite image analyses.

\section{Study Area}

The eastern shelf region of the Bering Sea $\left(2.29 \times 10^{6} \mathrm{~km}^{2}\right.$ in area), where the Yukon River plume is mainly dispersed, is $50-70 \mathrm{~m}$ deep on average. The region at a distance of less than ca. $170 \mathrm{~km}$ off the delta front is very shallow at less than $30 \mathrm{~m}$ in depth, which is due to sedimentation from sediment load of the Yukon River and the surrounding rivers (Figure 1) [20]. Behaviors of the Yukon sediment plume and the consequent dis- 
persion of the plume-suspended sediment was considered to be controlled by the northern movement of the "Alaskan Coastal Water" [20-22], which was connected to the bottom distribution of clay minerals on the Alaskan-Chukchi margin [23].

Most of the Yukon River drainage basin (area, $8.55 \times 10^{5} \mathrm{~km}^{2}$ ) is located in the subarctic region south of the Arctic Circle $\left(66^{\circ} 33^{\prime} \mathrm{N}\right)$, and is occupied by $74.8 \%$ forest with discontinuous permafrost and 1.1\% glacierized area in Alaska Range, Wrangell Mts., St. Elias Mts., etc. [24-27]. Site PLS is the lowest gauging station of the U.S. Geological Survey (USGS) at ca. $170 \mathrm{~km}$ upstream of sites ALK and site EMK, base villages for the coastal observations (Figure 1). The drainage area upstream of site PLS is $3.21 \times 10^{5} \mathrm{~km}^{2}$, and at site PLS, annual discharge, annual sediment load and annual sediment yield were $1.97 \times 10^{2} \mathrm{~km}^{3} / \mathrm{yr}, 44.5 \mathrm{Mt} / \mathrm{yr}$ and $53.5 \mathrm{t} / \mathrm{km}^{2} / \mathrm{yr}$ in 2007 and 2008, respectively [26]. Hence, of the six largest rivers in the subarctic to arctic regions (MacKenzie in Canada, Yukon in USA/Canada, and Amur, Lena, Ob and Yenisei in Russia), the Yukon River is the $6^{\text {th }}$ largest river for annual discharge, but the second largest river for annual sediment load (the top is MacKenzie at $100 \mathrm{Mt} / \mathrm{yr}$ ) and the largest river for annual sediment yield [28]. Suspended sediment in the Yukon River, which is fine-grained with more than $90 \%$ wt. silt and clay, mostly originates in the glacierized mountainous area [26,27]. The Yukon River delta is fan-shaped with branching the Yukon River channel into some smaller river channels, and thus the river sediment plume tends to be dispersed around the coastal line of the delta front (Figure 1b).

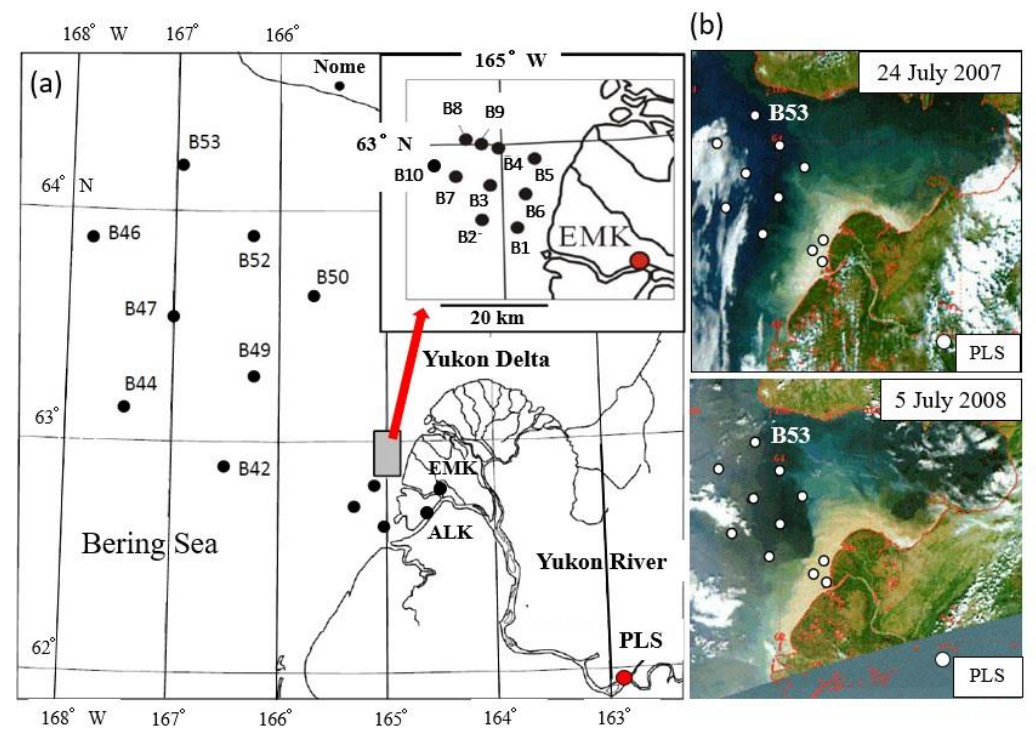

Figure 1. (a) Location of observation sites, B42 - B53, offshore from the Yukon River delta on 1-2 August 2007 and 2-4 July 2008; (b) Clear RGB (red-green-blue color model) satellite images of MODIS/Terra (2250h, 25 July 2007 and 2315h, 5 July 2008 in GMT) for the Yukon sediment plume, taken on the dates closest to the observations. The label "PLS" shows the location of the USGS Yukon River gauging station. The "ALK" and "EMK" are base villages for coastal observations (observation sites; three black circles with no name and sites B1 - B10) near the Yukon delta front [29].

\section{Methods}

\subsection{Field Observations}

In order to explore behaviors of the sediment plume released from the Yukon River delta, observations in the coastal and offshore regions were undertaken by an outboard and a research training ship, the Oshoro-maru (1,396 ton in weight), Faculty of Fisheries Sciences, Hokkaido University, respectively (Figure 1). 
The observations by the Oshoro-maru were conducted on 1-2 August 2007 and 24 July 2008. The observation in 2007 started at site B42 at 1235h, 1 August and ended at site B53 at 1831h, 2 August, and that in 2008 started at site B42 at 2320h, 2 July and ended at site B53 at 0253h, 4 July. Thus, the observations in 2007 and 2008 took ca. $30 \mathrm{hrs}$ and ca. $28 \mathrm{hrs}$ for all the sites, respectively. Here, all the shipboard observation times are denoted by the Alaska Daylight Time (AKDT), since the time sereis of Yukon River discharge and sediment load at site PLS were acquired at the AKDT.

At eight sites, sites B42 to B53, at less than $172 \mathrm{~km}$ northwest of the delta front (Figure 1a), where the surface sediment plume was visually ascertained, vertical profiles of water temperature, electric conductivity at $25^{\circ} \mathrm{C}$ (EC25) and water turbidity were obtained at $0.1 \mathrm{~m}$ pitch by a TCTD (turbidity-conductivity-temperature-depth) profiler (model ASTD687, JFE Advantech, Co., Ltd., Japan), and water and bottom sediment were sampled. The water turbidity, $\mathrm{x}(\mathrm{ppm})$ was changed into suspended sediment concentration, $\mathrm{y}\left(\mathrm{SSC} ; \mathrm{mg} / \mathrm{L}\right.$ ) by using a regression curve, $\mathrm{y}=1.597 \mathrm{x}^{0.8119}$ at $\mathrm{x}=0-160 \mathrm{ppm}$ $\left(\mathrm{R}^{2}=0.932, \mathrm{p}<0.01\right)$. The regression curve was acquired from plots between the turbidity and the SSC of surface water sampled simultaneously on the ship. The SSC was obtained by filitering a certain volume of sampled water with the glass filter GF/B (1.0 $\mu \mathrm{m}$ opening) and weighing the dried filters. Also, the EC25 values in $\mathrm{mS} / \mathrm{m}$ were converted into $\mathrm{NaCl}$ (\%) water as salinity by the linear relationship $\left(R^{2}=0.992, p<0.001\right)$ between EC25 and salinity. Here, water density $\sigma_{\mathrm{T}}$ was calculated by $\sigma_{\mathrm{T}}=\rho(\mathrm{S}, \mathrm{T}, 0)-1000$, where $\rho(\mathrm{S}, \mathrm{T}, \mathrm{P})$ is water density $\left(\mathrm{kg} / \mathrm{m}^{3}\right)$ and a function of salinity $\mathrm{S}(\% \mathrm{o})$, water temperature $\mathrm{T}\left({ }^{\circ} \mathrm{C}\right)$ and pressure $\mathrm{P}$ (= 0 at $1 \mathrm{~atm})$. Bottom sediment was sampled at the eight sites by an EkmanBirge grab sampler. The sediment was ca. $0.1 \mathrm{~m}$ thick below the bottom surface.

During the measurements of the Yukon River discharge and sediment load at site PLS, vertical profiles of water temperature, EC25 and water turbidity were acquired at the three sites (three black circles near site ALK in Figure 1) in coastal regions by using the same profiler on 7 June and 9 September 2008. Then, bottom sediment was also sampled by the grab sampler. At sites B1 to B10 (black circles in the inserted map of Figure 1a), similarly, the profiles and bottom sediment were obtained in September 2009 and June 2010 [29]. These coastal observations were peformed to explore relations between the Yukon plume's behavior and the river discharge and sediment load, and to connecct them to the observational results at sites B42 to B53. In order to know the sedimentary process by the sediment plume, the grain size of the bottom sediment was related to that of the bottom sediment at sites B42 to B53.

At site PLS, ca. $170 \mathrm{~km}$ upstream of the delta front, time series of hourly and daily mean sediment load were obtained in June 2006 - September 2009 by using the suspended sediment concentration (SSC; $\mathrm{g} / \mathrm{L}$ ) converted from water turbidity $(\mathrm{ppm})$ and the river discharge data of USGS (U.S. Geological Survey) (URL: http://waterdata.usgs.gov/nwis/dv/?site_no=15565447\&agency_cd=USGS\&referred_module=sw (accessed on 7 May 2021)) [26]. The discharge is acquired by applying the H-Q rating curve from recorded river stage, $\mathrm{H}(\mathrm{m})$ and simultaneously measured discharge, $\mathrm{Q}\left(\mathrm{m}^{3} / \mathrm{s}\right)$ by USGS, which is updated every year. Hourly and daily mean time series of water temperature were also obtained at site PLS by a temperature logger (TidbiT v2, Onset Computer, Inc., USA) [26].

In order to explore the influence of wind-driven currents on the dispersion of surface sediment plume, the hourly wind velocity data at the airports of site EMK and Nome were utilized (URL: https://www.wunderground.com/history/daily/us/ak/emmonak, URL: https://www.wunderground.com/history/daily/us/ak/nome (accessed on 2-10 August 2021)) (Figure 1a). The hourly wind data were then compiled into the data of daily mean wind speed and direction, which were applied to judge if the wind-driven currents promote or suppress the northwestern dispersion of the surface sediment plume. 
Relatively clear RGB (red-green-blue color model) composite images of MODIS/Terra from the NASA oceanic web site (URL: http://oceancolor.nasa.gsfc.gov (accessed on 19 and 24 February 2021)) closest to the dates of the marine observations are shown in Figure 1b. The horizontal distributions of the surface sediment plumes on the images indicate that the B50-B53 line was relatively close to the center line of the sediment plume extending northwestward, and that site B53 was located near a farthest margin of the plume.

\subsection{Laboratory Experiments}

The bottom sediments sampled at sites B42 to B53 and the 13 sites in the coastal region were analyzed for the grain size by the photo-extinction method with a centrifuge for particles of grain size $\mathrm{d} \leq 44 \mu \mathrm{m}$ (micrometers) and by the sieving method for $\mathrm{d}>44$ $\mu \mathrm{m}$ particles [26]. In order to ascertain the flocculation level of river-suspended sediment, the salinity effect on the grain size of suspended sediment was explored by increasing salinity in pure water, and mineralogical analyses were conducted by the XRD (X-ray diffraction) method for the bottom sediment and suspended sediment in sampled water [29]

\subsection{Image Analysis}

In order to know hydrological effects of the Yukon River on behaviors of the surface sediment plumes in the Bering Sea, the plumes' area during the monitoring of river stage and turbidity at site PLS was numerically obtained by using the Aqua Level 1 Products from the NASA oceanic web site mentioned before. Three near infrared bands (wavelength; 667, 748 and $869 \mathrm{~nm}$ ) of MODIS/Aqua or MODIS/Terra were applied to each image for scaling suspended sediment concentration (SSC) of the plume. Here, the satellite observed reflectance $\mathrm{L}_{\mathrm{T}}$ for each of wavelengths, 667, 748 and $869 \mathrm{~nm}$ is given as follows:

$$
\begin{aligned}
& \mathrm{LT}_{(667)}=\mathrm{LM}(667)+\mathrm{LA}_{(667)}+\mathrm{t}(667) \mathrm{Lw}_{\mathrm{w}}(667), \\
& \mathrm{LT}(748)=\mathrm{Lм}(748)+\mathrm{LA}(748)+\mathrm{t}(748) \mathrm{Lw}_{w}(748), \\
& \mathrm{LT}_{\mathrm{T}}(869)=\mathrm{LM}(869)+\mathrm{LA}(869)+\mathrm{t}(869) \mathrm{Lw}_{\mathrm{w}}(869) \text {, }
\end{aligned}
$$

where LM is the reflectance due to gas molecules, $\mathrm{LA}_{\mathrm{A}}$ is the reflectance due to aerosol particles, Lw is the reflectance due to water body (our target), and $t$ is the diffuse transmittance between sea surface and satellite on the assumption of single scattering. This assumption requires that neither the single scattering albedo nor the phase function depends on wavelengths. Also, the reflectance La by aerosol particles is supposed to follow the Ångström' law as follows:

$$
\mathrm{L}_{\mathrm{A}}(\lambda) \cong\left(\frac{\lambda}{869}\right)^{-\alpha} \frac{\mathrm{F}_{0}(\lambda)}{\mathrm{F}_{0}(869)} \mathrm{L}_{\mathrm{A}}(869)
$$

where $\lambda$ is the wavelength (nm), $\alpha$ is the Angström exponent, and $\mathrm{F}_{0}$ is the extraterrestrial solar irradiance. Here, the reflectance LA at a certain wavelength is assumed to be nearly equal to that normalized by the parameters at $\lambda=869 \mathrm{~nm}$. Then, $\mathrm{L}_{\mathrm{w}}$ in Equations (1) - (3) is given in the following:

$$
\begin{aligned}
& \operatorname{Lw}_{w}(667)=\operatorname{Rrs}(667) \cdot \mathrm{F}_{0}(667) \cdot \cos \theta_{0} \cdot \mathrm{t}_{0}(667), \\
& \mathrm{Lw}_{\mathrm{w}}(748)=\operatorname{Rrs}_{\mathrm{rs}}(748) \cdot \mathrm{F}_{0}(748) \cdot \cos \theta_{0} \cdot \mathrm{t}_{0}(748),
\end{aligned}
$$




$$
\mathrm{Lw}_{\mathrm{w}}(869)=\mathrm{Rrs}_{\mathrm{rs}}(869) \cdot \mathrm{F}_{0}(869) \cdot \cos \theta_{0} \cdot \mathrm{t}_{0}(869),
$$

where $\theta_{0}$ is the solar zenith angle, to $(\lambda)$ is the diffuse transmittance between the sun and sea surface at a wavelength $\lambda$, and $\operatorname{Rrs}(\lambda)$ is the remote-sensing reflectance at $\lambda$. Here, two parameters, $\alpha$ and $\mathrm{LA}_{\mathrm{A}}(869)$ in Equation (4) and the relationship between $\mathrm{R}_{\mathrm{rs}}(\lambda)$ and SSC $(\mathrm{mg} / \mathrm{L})$ at or near water surface in Equations (5) - (7) are unknown. Hence, if certain $\alpha$ and $\mathrm{LA}_{\mathrm{A}}(869)$ values are given, the relationship between $\mathrm{R}_{\mathrm{rs}}$ and SSC is obtained for the wavelengths, $667 \mathrm{~nm}, 748 \mathrm{~nm}$ and $869 \mathrm{~nm}$. As a result, following relations were obtained in case of the East China Sea and Yellow Sea [30]:

$$
\begin{aligned}
& \operatorname{Rrs}(667)=0.000561 \cdot C^{1.1156}\left(R^{2}=0.692, p<0.01\right), \\
& \operatorname{Rrs}(748)=0.0000854 \cdot C^{1.140}\left(R^{2}=0.607, p<0.01\right), \\
& \operatorname{Rrs}(869)=0.0000763 \cdot C^{0.997}\left(R^{2}=0.849, p<0.01\right),
\end{aligned}
$$

where C is SSC (mg/L) in situ at or near water surface. Finally, using Equations (8)-(10), the Lw values were calculated from Equations (5)-(7), and then compared with the shipobserved SSC values. In this study, the following relationship was applied:

$$
C=0.657 \cdot C_{\text {sat }}{ }^{1.32} \quad\left(R^{2}=0.723, p<0.01\right),
$$

where $\mathrm{C}_{\text {sat }}$ is SSC $(\mathrm{mg} / \mathrm{L})$ at or near water surface from MODIS/Aqua or MODIS/Terra images. Equation (11) is applicable for $\mathrm{C}_{\text {sat }}<\sim 20 \mathrm{mg} / \mathrm{L}$. Clear RGB Images in June-September of 2005-2009 were adopted for scaling the SSC of sediment plumes.

In Equation (11), there is not the 1:1 correspondence between $C$ and $C_{\text {sat }}$ such as in Zang et al. [31], where the SWIR method by Wang et al. [32] and the NIR iterative method in the analysis software, SeaDAS (URL: https://seadas.gsfc.nasa.gov/ (access on 6 May 2021)), were adopted for the atmospheric correction to retrieve SSC at a wide range of the 0.1 to $100 \mathrm{mg} / \mathrm{L}$ order. Doxaran et al. [33] obtained the linear relationship between C and $\mathrm{C}_{\text {sat }}$ from MODIS/Aqua or MODIS/Terra images for the high SSC of 100-2000 mg/L.

\section{Results}

\subsection{Sediment Plume Behaviors by Field Observations}

Figure 2 shows cross-sections of SSC, water temperature, salinity and water density $\sigma_{\mathrm{T}}$ along the B50 to B53 line on 2 August 2007 (Figure 1). The observation along the line

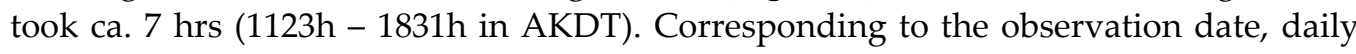
mean values of SSC, discharge, sediment load and water temperature at site PLS were $287 \mathrm{mg} / \mathrm{L}, 1.06 \times 10^{4} \mathrm{~m}^{3} / \mathrm{s}, 3.04 \times 10^{3} \mathrm{~kg} / \mathrm{s}$ and $17.9^{\circ} \mathrm{C}$ on 31 July 2007 , respectively, where 2 days (equal to the distance, $170 \mathrm{~km}$, divided by rough riverflow speed, $1 \mathrm{~m} / \mathrm{s}$ ) were considered as an approximate time needed to flow downstream from site PLS to the delta front. The 21-day values averaged for 11 - 31 July 2007 at site PLS were $318 \mathrm{mg} / \mathrm{L}$ for SSC, $1.04 \times 10^{4} \mathrm{~m}^{3} / \mathrm{s}$ for discharge, $3.33 \times 10^{3} \mathrm{~kg} / \mathrm{s}$ for sediment load and $18.6^{\circ} \mathrm{C}$ for water temperature. Here, more 20 days (equal to the distance, $172 \mathrm{~km}$, divided by supposed plume speed, $0.1 \mathrm{~m} / \mathrm{s}$ ) were considered as another approximate time needed to northwesterly flow from the delta front to site B53, one of the farthest points (Figure 1). There was no 
large difference (less than $10 \%$ ) between the daily mean of July 31 and the 21-day mean values.
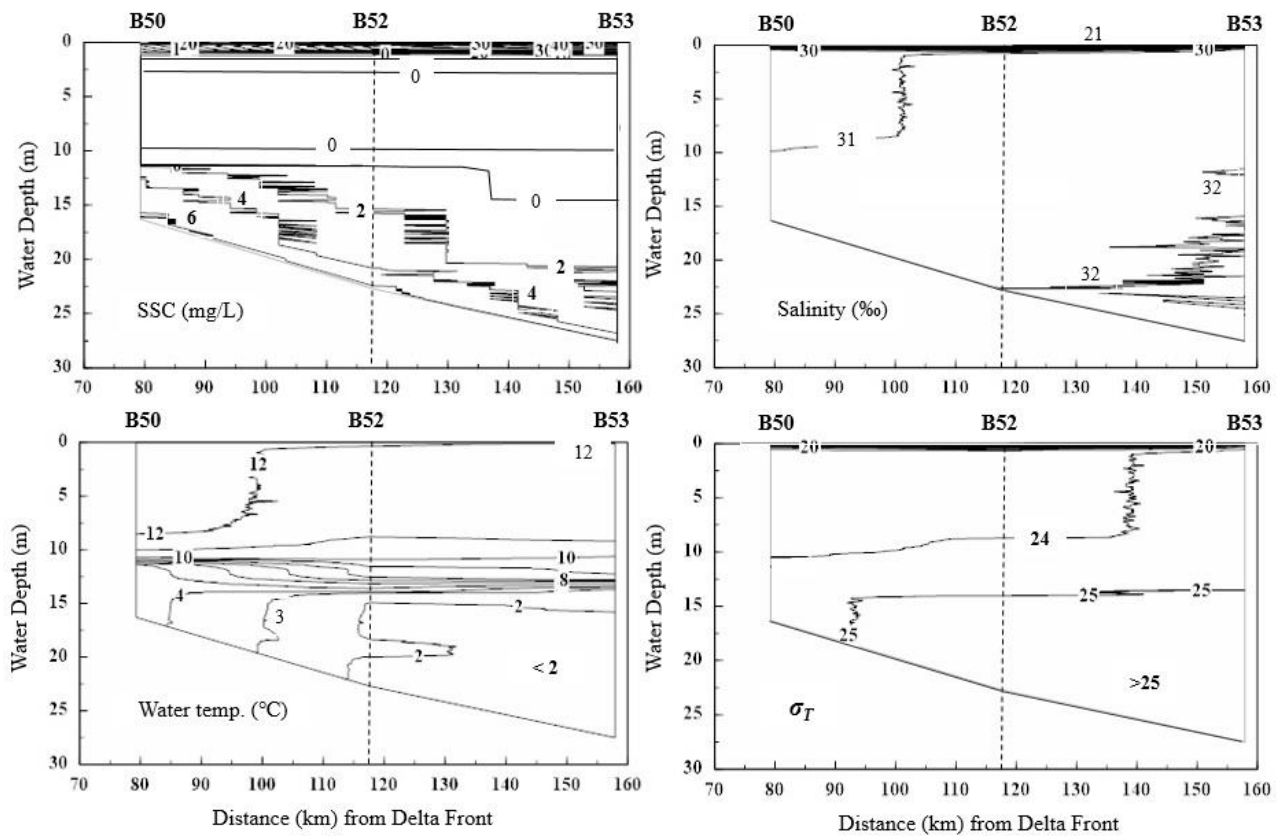

Figure 2. Cross-sectional distributions of SSC, water temperature, salinity and water density $\sigma_{1}$ on the B50 - B53 line obtained on 2 August 2007 (see Figure 1).
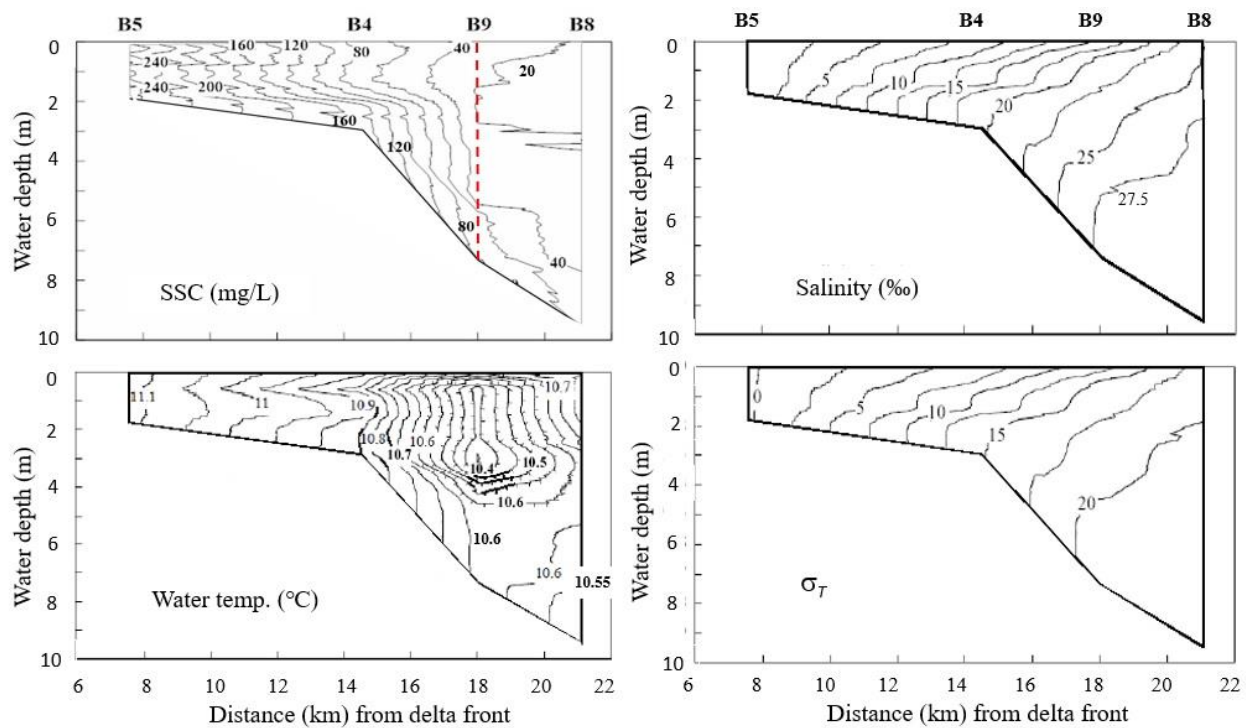

Figure 3. Longitudinal cross-sections of SSC, water temperature, salinity, and water density $\sigma_{\mathrm{T}}$ by the coastal observation on the B5-B8 line on 6 September 2009 (Figure 1) [29]. The red dotted line in the SSC cross-section shows a boundary of separation into surface sediment plume and density underflow.

There was a surface layer at less than $2 \mathrm{~m}$ in depth, accompanied by relatively high SSC and low salinity, which clearly depicts the existence of the buoyant surface sediment plume. Meanwhile, a slightly high SSC layer ca. $5 \mathrm{~m}$ thick existed just above the bottom, exhibiting the downslope protrusive distribution of $2-3{ }^{\circ} \mathrm{C}$ in temperature. This suggests that a turbid density underflow occurred after the plunging of turbid water in the coastal region. In the coastal observations in 2009 and 2010, Chikita et al. [29] revealed that the plunging followed by the underflow occurs at Yukon River sediment load of more than ca. $2,500 \mathrm{~kg} / \mathrm{s}$ (Figure 3). At the boundary shown by the red vertical line in Figure 3, the underflow appears to have coincided with the liftoff to a surface sediment plume [1]. 
Then, the corresponding sediment load and discharge at site PLS were $2.89 \times 10^{3} \mathrm{~kg} / \mathrm{s}$ and $7.39 \times 10^{3} \mathrm{~m}^{3} / \mathrm{s}$, respectively. The water temperature distribution in Figure 3 indicates that, at such a boundary, the vertical mixing prevailes. The river sediment load for the shipboard observation of August 2007 was more than 3,000 kg/s. Hence, the separation into sediment surface plume and density underflow in Figure 2 likely occurred in the coastal zone along the delta front.

Originally, the river water density $\sigma$ r at site PLS on 31 July 2007 was -1.12 for SSC at $287 \mathrm{mg} / \mathrm{L}$, water temperature at $17.9{ }^{\circ} \mathrm{C}$ and salinity at $0.113 \%$. Thus, the river water should not be heavier than the marine water of $\sigma_{\mathrm{T}}=25-26$ on 2 August 2007, even if the mixing of river water with marine water occurs in the coastal area. Hence, the turbid underflow in Figure 2 is considered to have been initiated by the nepheloid layer formation [18] from the flocculation of fine-grained (more than $90 \% w t$. silt and clay; grain size $\mathrm{d}<0.063 \mathrm{~mm}$ ) suspended sediment, which was supplied mainly by the glacier-melt sediment runoffs of the Yukon River in June to September [29].

The density underflow observed is unlikely to have been produced by the resuspension of bottom sediment by tidal, littoral or wind-driven currents, because, in the coastal region, the high SSC bottom layer followed by the plunging was formed in the relatively deep zone [29]. The wind at site EMK during the observation in Figure 3 was weak at $1.3 \mathrm{~m} / \mathrm{s}$ northwesterly on average, thus blowing onshore. Hence, the resuspension by wind-driven currents is again probably low, because the separation into surface sediment plume and density underflow in Figure 3 appears to have occurred under the flow energy decay in the mixing zone.
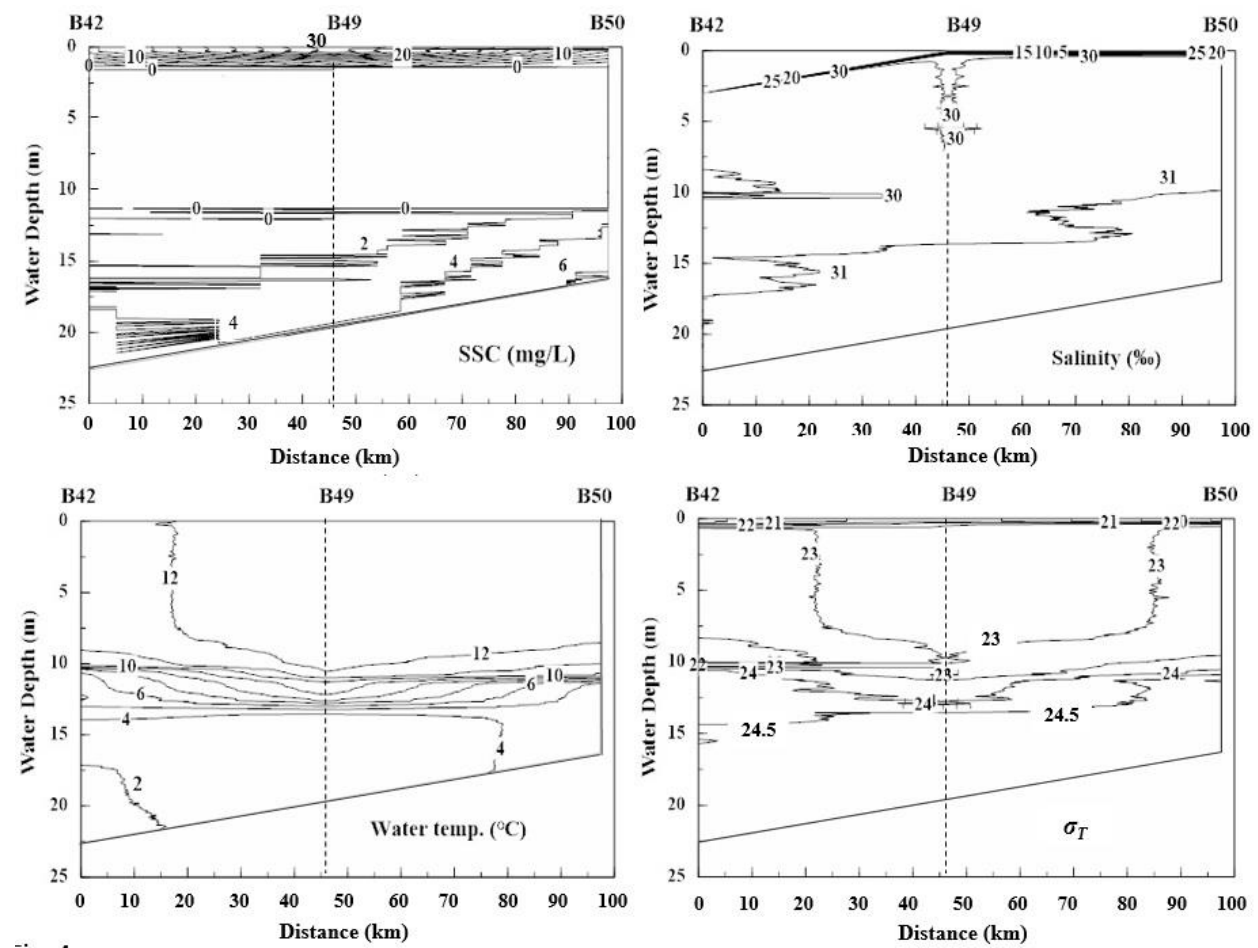

Figure 4. Cross-sectional distributions of SSC, water temperature, salinity and water density $\sigma \mathrm{T}$ on the B42 - B50 line obtained on 1-2 August 2007 (see Figure 1).

There existed a clear thermocline of $4-10^{\circ} \mathrm{C}$ at $10-15 \mathrm{~m}$ in depth with a small salinity range of 31-32\%, which separated the upper warm brackish layer from the lower cold marine water. However, the whole layer, including the thermocline, was pycnally stratified by increasing $\sigma \mathrm{T}$ from 20 to 25 downward.

Figure 4 show cross-sectional distributions of SSC, water temperature, salinity and water density $\sigma_{\mathrm{T}}$ on the B42 - B50 line for 1235h, 1 August - 1253h, 2 August 2007 (Figure 1). On the traverse line, the SSC in the lower layer increased toward site B50, suggesting 
the center of the turbid underflow near site B50 or in more northeastward regions (Figure 1). On the farther traverse B44-B52 line, the SSC zone of 4-6 mg/L in the lower layer became unclear, compared with that on the B42-B50 line. This is probably due to the flow energy dissipation by lateral spreading of the underflow during the downslope movement [34]. The thermocline at depths of 10-15 $\mathrm{m}$ was still clear on the traverse lines. The cold marine water at water temperature $1-2{ }^{\circ} \mathrm{C}$, salinity ca. $32 \%$ and $\sigma_{\mathrm{T}}=25-26$ thus existed consistently in a lower layer under the surface sediment plume.
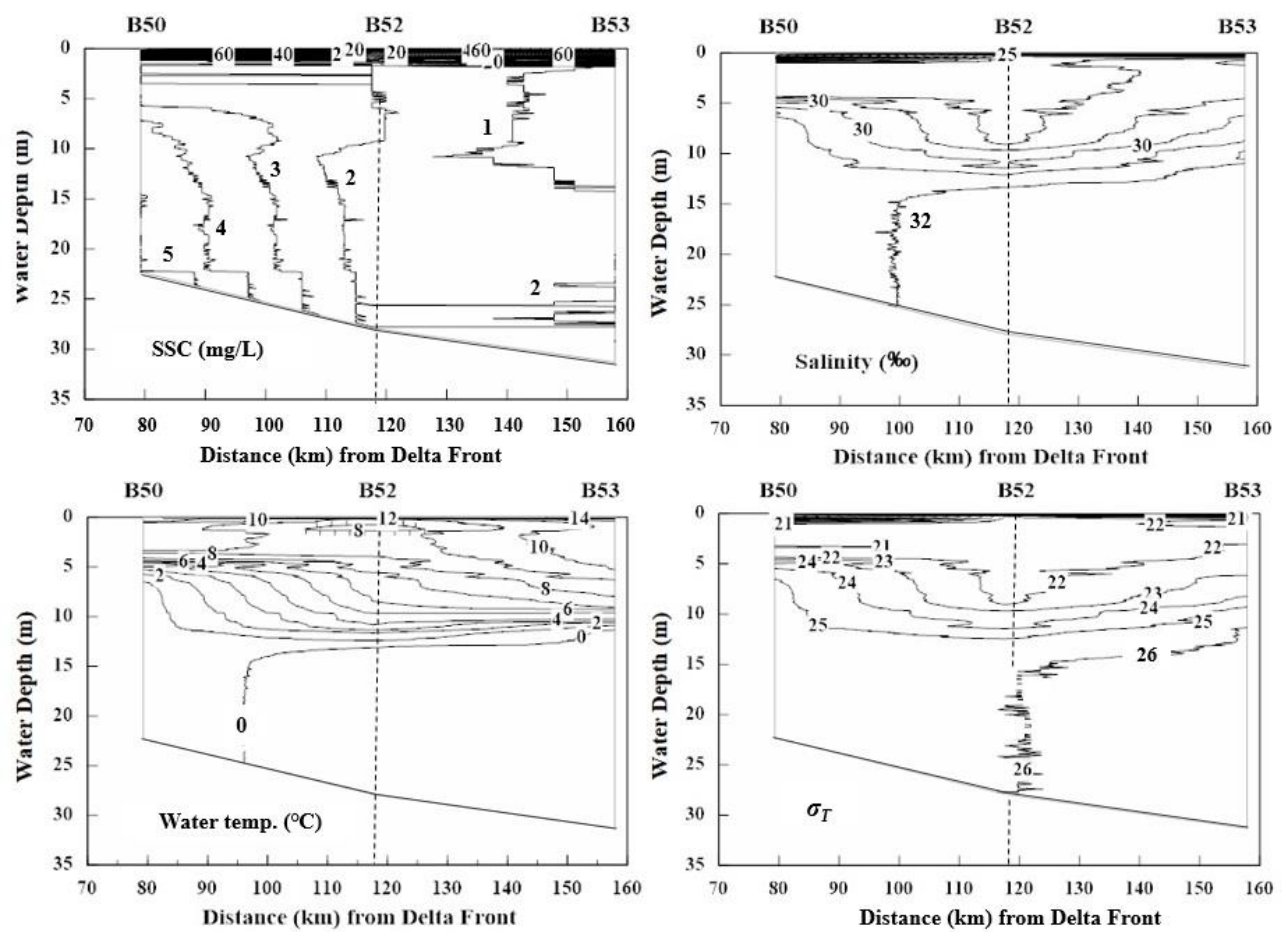

Figure 5. Cross-sectional distributions of SSC, water temperature, salinity and water density бт on the B50 - B53 line obtained on 3 - 4 July 2008 (see Figure 1).

Figure 5 shows longitudinal cross-sections of SSC, water temperature, salinity and water density $\sigma_{\text {т }}$ along the B50 to B53 line in July 2008 (Figure 1). The observation took ca. 7 hrs (1950h, 3 July - 0253h, 4 July). Daily mean SSC, discharge, sediment load and water temperature at site PLS were $112 \mathrm{mg} / \mathrm{L}, 1.18 \times 10^{4} \mathrm{~m}^{3} / \mathrm{s}, 1.32 \times 10^{3} \mathrm{~kg} / \mathrm{s}$ and $16.7^{\circ} \mathrm{C}$ on 1 July 2008. Similarly, the 21 -day averaged values at site PLS were $116 \mathrm{mg} / \mathrm{L}, 1.37 \times 10^{4}$ $\mathrm{m}^{3} / \mathrm{s}, 1.60 \times 10^{3} \mathrm{~kg} / \mathrm{s}$ and $14.6^{\circ} \mathrm{C}$ for 11 June- 1 July 2008 . The SSC and sediment load were less than half of 31 July 2007 or 10-31 July 2007 (Figure 2), though the discharge was ca. $20 \%$ larger. A surface high SSC layer clearly existed as a surface sediment plume, but a near-bottom layer of relatively high SSC was not seen in any cross-sections. Instead, the high SSC zone of $1-5 \mathrm{mg} / \mathrm{L}$ was extensively distributed from the surface sediment plume to the lower layer including the cold marine water. This suggests that, at sediment load of less than ca. $2,500 \mathrm{~kg} / \mathrm{s}$, neither a nepheloid layer nor density underflow is produced in the coastal zone.

Actually, the coastal observation on 22 June 2010, when the corresponding sediment load and discharge at site PLS were $2.19 \times 10^{3} \mathrm{~kg} / \mathrm{s}$ and $9.12 \times 10^{3} \mathrm{~m}^{3} / \mathrm{s}$ on $20 \mathrm{June} 2010$, respectively, did not show any separation into surface plume and density underflow, but the offshore extension of the mixing zone with vertically uniform SSC [29]. In the more offshore region, then, the formation of surface sediment plume, not accompanied by density underflow, is supposed as in Figure 5.

The dynamical difference shown by Figure 2 and 5 thus leads to a conclusion that, at the Yukon sediment load of more than ca. 2,500 kg/s, the nepheloid layer from floccu- 
lation of suspended sediment and the separation into surface sediment plume and density underflow could occur in the mixing zone and in the more offshore region, respectively.

\subsection{Analytical Results for Grain Size of Bottom Sediment}

Figure 6 shows spatial distributions of mean size and standard deviation in grain size of bottom sediments sampled at sites B42 to B53 and in the coastal regions (three black circles with no label in Figure 1a) in 2008. The grains became gradually fine toward site B50 from the delta front with gradual unsorting (increasing standard deviation). This means that the sediment was deposited following the seaward sediment sorting from the delta front as shown by the gray arrow in Figure 6 [35]. This sorting is probably based on the downslope movement of the turbid underflow under condition of the high Yukon sediment load at more than ca. 2,500 kg/s. The mean size of the bottom sediment was minimum at $75 \mu \mathrm{m}$ near site B50 (Figure 6a). Hence, the flowing distance is probably about $90 \mathrm{~km}$ (Figure 2) as a limit of northwestward movement of the underflow. The sediment sorting has a southwestern boundary as shown by red dotted lines in Figure 6, probably corresponding to a lateral boundary of the underflow. In fact, in the traverse cross-section of Figure 4, the bottom layer of relatively high SSC at $>\sim 4 \mathrm{mg} / \mathrm{L}$ becomes thick toward site B50 from near site B49. This indicates that the underflow's center existed to the northeast of site B49.
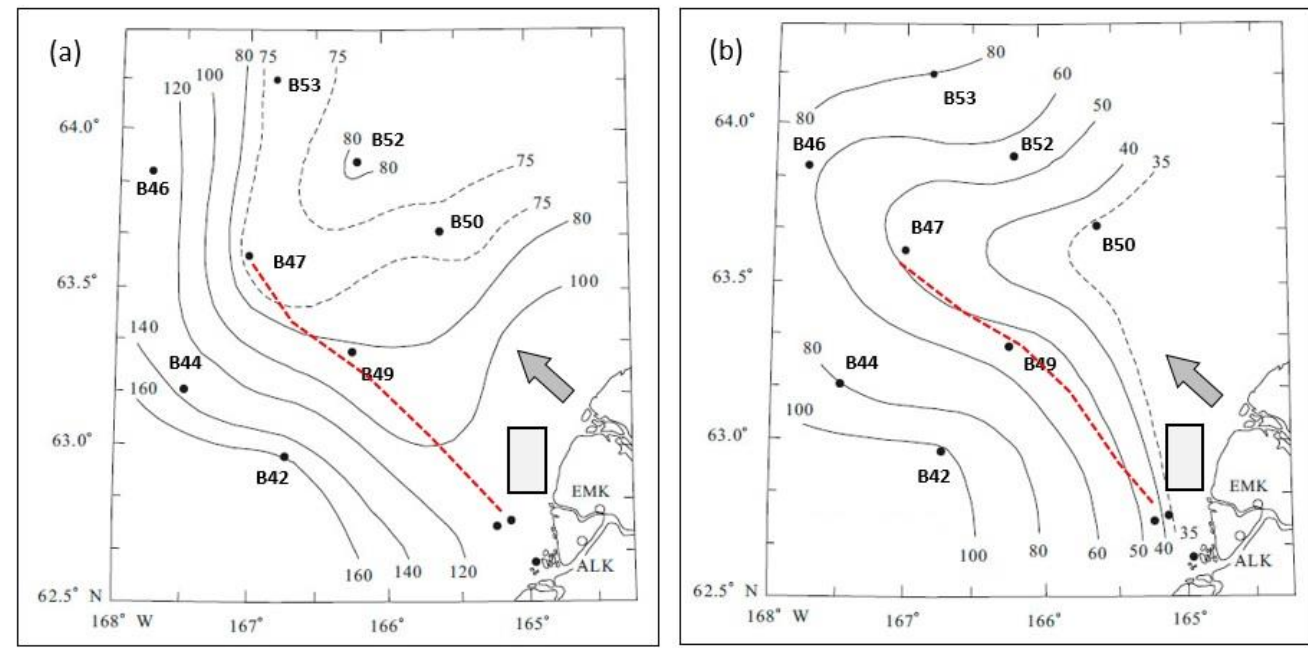

Figure 6. Spatial distributions of (a) mean size $(\mu \mathrm{m})$ and (b) standard deviation in the grain size of the bottom sediments sampled in 2008. The red dotted lines show southwestern boundaries of the sediment sorting probably by the turbid underflow flowing northwestward (gray arrow) from the coastal region.

\subsection{Analytical Results for the Satellite Images}

Figure 7 shows an example analyzed for a MODIS/Aqua image of the Yukon surface plume by using the three near infrared bands [30]. The image was taken at 0010h, 7 July 2008 (GMT), thus being close to the observation date of 2-4 July 2008 (Figure 5). Figure 7 shows (a) the RGB composite image, (b) the distribution of SSC, C=2-20 mg/L, off the delta front, (c) the two subareas of $20 \geq \mathrm{C}>4 \mathrm{mg} / \mathrm{L}$ (blue) and $4 \geq \mathrm{C} \geq 2 \mathrm{mg} / \mathrm{L}$ (red), and (d) the area analyzed (inside the yellow rectangle). Here, it is out of scale for $C>20$ $\mathrm{mg} / \mathrm{L}$ in the coastal region (Figure $7 \mathbf{b}$ ), and the surface plume area in the area closed by a yellow rectangle in Figure $7 \mathbf{d}\left(6.13 \times 10^{4} \mathrm{~km}^{2}\right.$; lat. $62^{\circ} 00^{\prime} 00^{\prime \prime}-64^{\circ} 32^{\prime} 30^{\prime \prime} \mathrm{N}$, long. $162^{\circ} 24^{\prime} 00^{\prime \prime}-167^{\circ} 45^{\prime} 00^{\prime \prime} \mathrm{W}$ ) was numerically obtained as the Yukon plume area. The black zone in the coastal regions in Figure $7 \mathbf{b}, 7 \mathbf{c}$ and $\mathbf{7 d}$ was produced by high reflection intensity at the shallow bottom. The surface plume area was calculated by adding such a 
black zone to the blue and red zones. Consequently the surface plume area in Figure 7c was evaluated at $24,670 \mathrm{~km}^{2}$.
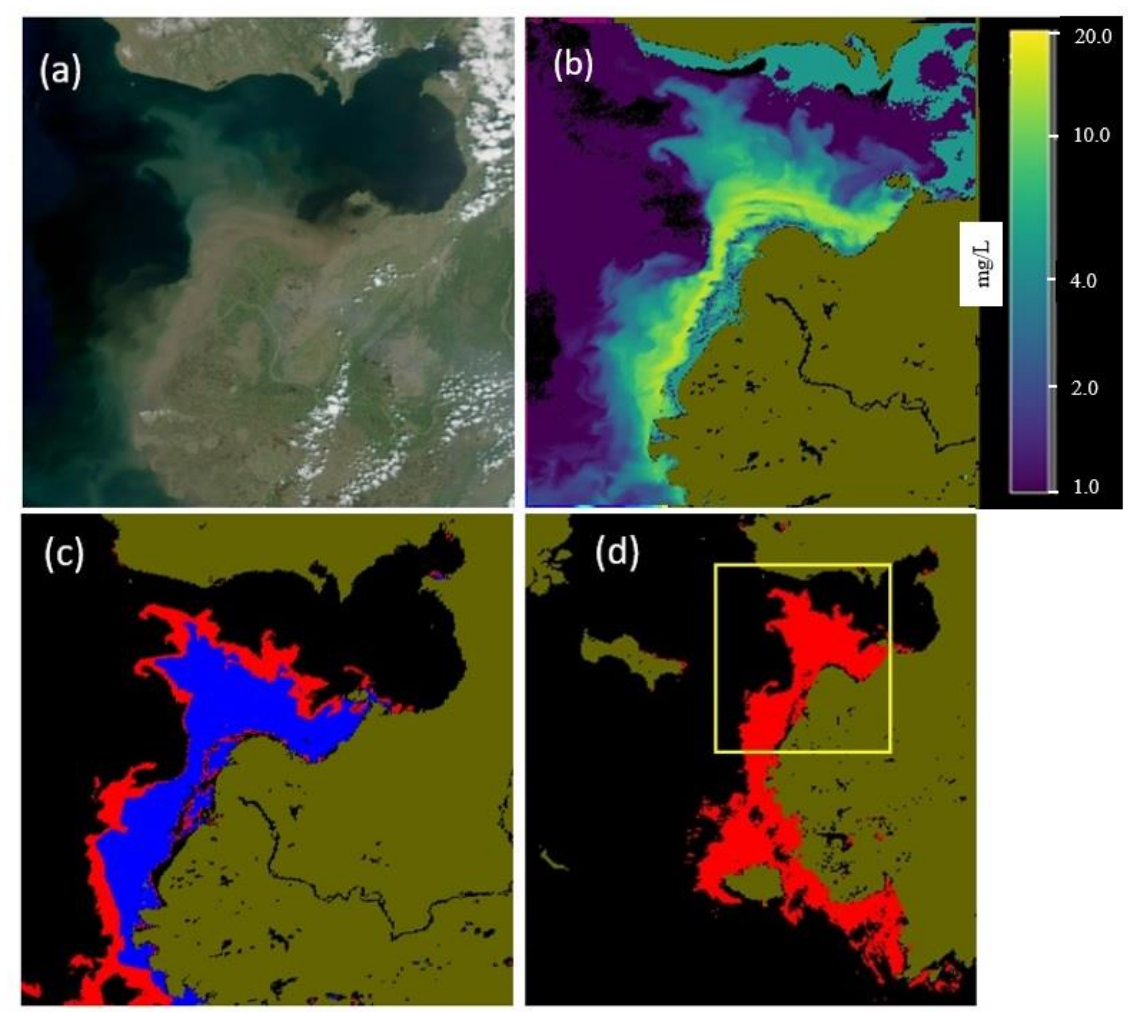

Figure 7. Analytical result for SSC, C (mg/L), from a MODIS/Aqua image (0010h, 7 July 2008; GMT). (a) RGB (red-green-blue color model) composite image, (b) SSC distribution by the three near-infrared bands, (c) two regions separated by $20 \geq \mathrm{C}>4 \mathrm{mg} / \mathrm{L}$ (blue) and $4 \geq \mathrm{C} \geq 2 \mathrm{mg} / \mathrm{L}$ (red), and (d) the area (yellow rectangle) analyzed for the surface sediment plume at $\mathrm{C} \geq 2 \mathrm{mg} / \mathrm{L}$ (red zone and black zone near the coastal region).

Table 1 shows a list of surface sediment plume area obtained from the images of MODIS/Terra or MODIS/Aqua in 2005-2009. Sediment load and discharge at site PLS averaged over 21 days were calculated as those corresponding to each plume area. Here, as in the shipboard observations, two days and 22 days as two approximate times needed to flow downstream from site PLS to the delta, and to northwesterly flow from the delta front to site B53, one of the farthest points, respectively, were considered (Figure 1). For each satellite image of the surface plume, river discharge and sediment load at site PLS were averaged for the time period between the date delayed by 2 days and that delayed by 22 days to the date of the satellite image, e.g., for an image of 24 July, averaged over a period (21 days) between 2 July and 22 July with the time lags of 22 days and 2 days, respectively. Then, the GMT of a satellite image was changed into the Alaska Daylight Time (AKDT; GMT- 8 hrs).

Of the 37 images in Table 1, sediment load at site PLS was over 2,500 kg/s for 26 images, which included the large snowmelt sediment runoff as in the period of 21 May 9 June 2009. However, there are totally only 14 images with the period differing by more than a day, since the shooting time between Terra and Aqua is very close at $10-20 \mathrm{~min}$ or their orbital cycle is $99 \mathrm{~min}$. The error of plume area between Terra and Aqua for the consecutive shooting time of $99 \mathrm{~min}$ or less ranges over $2.9-7.1 \%$. Of the 14 images, the 8 images correspond to sediment load at more than $2,500 \mathrm{~kg} / \mathrm{s}$. Then, the sediment plume could be accompanied by density underflow as in Figure 2 . 
Table 1. Surface sediment plume area obtained from the MODIS/Terra or MODIS/Aqua images and sediment load and discharge at site PLS averaged over the corresponding period (totally 21 days) between the dates delayed by 2 days and 22 days to the date of each image.

\section{Discussion}

\subsection{Dynamic Conditions of Yukon Sediment Plume from Field Observations}

As shown by the satellite images in Figure $\mathbf{1 b}$ and 7 , the Yukon River sediment plume tends to extend northwestward from the Yukon delta. The B50 to B53 line in the shipboard observations was located near the center line of the sediment plume, where

\begin{tabular}{|c|c|c|c|c|c|c|}
\hline No. & $\begin{array}{c}\text { Terra }(\mathrm{T}) \text { or } \\
\text { Aqua }(\mathrm{A})\end{array}$ & $\begin{array}{c}\text { Time \& Date } \\
\text { (AKDT) }\end{array}$ & $\begin{array}{c}\text { Plume area } \\
\left(\mathrm{km}^{2}\right)\end{array}$ & 21-day period & $\begin{array}{c}\text { Discharge } \\
\left(\mathrm{m}^{3} / \mathrm{s}\right)\end{array}$ & $\begin{array}{c}\text { Sediment load } \\
(\mathrm{kg} / \mathrm{s})\end{array}$ \\
\hline 1 & $\mathrm{~T}$ & $14: 25,7 / 5 / 2005$ & 22829 & $6 / 13-7 / 3,2005$ & 17,193 & 2,569 \\
\hline 2 & A & $14: 35,7 / 5 / 2005$ & 23903 & 6/13-7/3, 2005 & 17,193 & 2,569 \\
\hline 3 & $\mathrm{~T}$ & $13: 55,7 / 5 / 2006$ & 29062 & $6 / 13-7 / 3,2006$ & 13,343 & 2,594 \\
\hline 4 & $\mathrm{~T}$ & $15: 30,7 / 5 / 2006$ & 29791 & $6 / 13-7 / 3,2006$ & 13,343 & 2,594 \\
\hline 5 & A & $15: 45,7 / 5 / 2006$ & 29625 & $6 / 13-7 / 3,2006$ & 13,343 & 2,594 \\
\hline 6 & $\mathrm{~T}$ & $14: 25,6 / 9 / 2007$ & 21940 & $5 / 18-6 / 7,2007$ & 8,028 & 953 \\
\hline 7 & A & $14: 40,6 / 9 / 2007$ & 22644 & 5/18-6/7, 2007 & 8,028 & 953 \\
\hline 8 & A & $16: 15,6 / 9 / 2007$ & 22644 & 5/18-6/7, 2007 & 8,028 & 953 \\
\hline 9 & $\mathrm{~T}$ & $14: 55,6 / 12 / 2007$ & 21206 & 5/21-6/10, 2007 & 8,679 & 1,024 \\
\hline 10 & $\mathrm{~A}$ & $15: 10,6 / 12 / 2007$ & 20907 & $5 / 21-6 / 10,2007$ & 8,679 & 1,024 \\
\hline 11 & $\mathrm{~T}$ & $15: 00,7 / 5 / 2007$ & 22492 & $6 / 13-7 / 3,2007$ & 12,062 & 1,813 \\
\hline 12 & $\mathrm{~T}$ & $15: 20,7 / 10 / 2007$ & 20149 & 6/18-7/8, 2007 & 11,524 & 1,935 \\
\hline 13 & A & $14: 50,7 / 25 / 2007$ & 20394 & 7/3-7/23, 2007 & 10,116 & 2,931 \\
\hline 14 & A & $14: 55,8 / 17 / 2007$ & 26142 & $7 / 26-8 / 15,2007$ & 10,837 & 3,637 \\
\hline 15 & A & $16: 35,8 / 17 / 2007$ & 26139 & $7 / 26-8 / 15,2007$ & 10,837 & 3,637 \\
\hline 16 & $\mathrm{~T}$ & $13: 35,7 / 5 / 2008$ & 23863 & $6 / 13-7 / 3,2008$ & 13,054 & 1,506 \\
\hline 17 & A & $15: 15,7 / 5 / 2008$ & 23825 & 6/13-7/3, 2008 & 13,054 & 1,506 \\
\hline 18 & $\mathrm{~T}$ & $14: 20,7 / 6 / 2008$ & 23524 & 6/14-7/4, 2008 & 12,907 & 1,498 \\
\hline 19 & A & $16: 10,7 / 6 / 2008$ & 24670 & 6/14-7/4, 2008 & 12,907 & 1,498 \\
\hline 20 & $\mathrm{~T}$ & $14: 30,8 / 21 / 2008$ & 22520 & $7 / 30-8 / 19,2008$ & 12,958 & 4,474 \\
\hline 21 & $\mathrm{~A}$ & $14: 45,8 / 21 / 2008$ & 23404 & $7 / 30-8 / 19,2008$ & 12,958 & 4,474 \\
\hline 22 & A & $16: 25,8 / 21 / 2008$ & 24344 & $7 / 30-8 / 19,2008$ & 12,958 & 4,474 \\
\hline 23 & $\mathrm{~T}$ & $15: 15,8 / 22 / 2008$ & 25454 & $7 / 31-8 / 20,2008$ & 13,042 & 4,745 \\
\hline 24 & A & $15: 30,8 / 22 / 2008$ & 24783 & $7 / 31-8 / 20,2008$ & 13,042 & 4,745 \\
\hline 25 & $\mathrm{~T}$ & $14: 20,8 / 23 / 2008$ & 26392 & 8/1-8/21, 2008 & 12,997 & 4,352 \\
\hline 26 & A & $14: 35,8 / 23 / 2008$ & 28191 & 8/1-8/21, 2008 & 12,997 & 4,352 \\
\hline 27 & A & $16: 10,8 / 23 / 2008$ & 28231 & $8 / 1-8 / 21,2008$ & 12,997 & 4,352 \\
\hline 28 & $\mathrm{~T}$ & $15: 00,8 / 24 / 2008$ & 26240 & $8 / 2-8 / 22,2008$ & 12,996 & 4,253 \\
\hline 29 & A & $15: 15,8 / 24 / 2008$ & 25808 & $8 / 2-8 / 22,2008$ & 12,996 & 4,253 \\
\hline 30 & $\mathrm{~T}$ & $14: 05,9 / 10 / 2008$ & 21907 & $8 / 19-9 / 8,2008$ & 11,260 & 2,221 \\
\hline 31 & A & $16: 00,9 / 10 / 2008$ & 22488 & $8 / 19-9 / 8,2008$ & 11,260 & 2,221 \\
\hline 32 & $\mathrm{~T}$ & $13: 55,6 / 11 / 2009$ & 29654 & $5 / 20-6 / 9,2009$ & 21,150 & 5,338 \\
\hline 33 & $\mathrm{~T}$ & $15: 30,6 / 11 / 2009$ & 31219 & 5/20-6/9, 2009 & 21,150 & 5,338 \\
\hline 34 & $\mathrm{~A}$ & $15: 50,6 / 11 / 2009$ & 30338 & $5 / 20-6 / 9,2009$ & 21,150 & 5,338 \\
\hline 35 & A & $15: 00,7 / 21 / 2009$ & 24565 & $6 / 29-7 / 19,2009$ & 14,187 & 2,797 \\
\hline 36 & $\mathrm{~T}$ & $14: 10,9 / 20 / 2009$ & 24189 & $8 / 29-9 / 18,2009$ & 7,757 & 3,872 \\
\hline 37 & A & $14: 30,9 / 20 / 2009$ & 26029 & 8/29-9/18, 2009 & 7,757 & 3,872 \\
\hline
\end{tabular}

the turbid underflow was also observed in the lower layer at relatively high sediment load of the Yukon River (Figure 2 and 3). A hydrodynamic condition of the underflow in Figure 2 and 3 is two-dimensionally judged by using the densimetric Froude number $\mathrm{F}_{\mathrm{d}}$ and Reynolds number $R_{e}$ in the following:

$$
\begin{aligned}
& \mathrm{F}_{\mathrm{d}}=\mathrm{U} /\left(\mathrm{g}^{\prime} \mathrm{D}\right)^{1 / 2}, \\
& \mathrm{R}_{\mathrm{e}}=\mathrm{UD} / \mathrm{v},
\end{aligned}
$$

where $\mathrm{U}$ is the underflow's velocity $(\mathrm{m} / \mathrm{s}), \mathrm{D}$ is the thickness $(\mathrm{m})$ of the underflow, $\mathrm{g}^{\prime}=\mathrm{g}$ $\cdot\left(\rho-\rho_{0}\right) / \rho_{0}$ (g: acceleration due to gravity in $\mathrm{m} / \mathrm{s}^{2}, \rho:$ underflow's density in $\mathrm{kg} / \mathrm{m}^{3}, \rho_{0}:$ am 
bient water density in $\left.\mathrm{kg} / \mathrm{m}^{3}\right)$, and $v$ is the kinematic viscosity $\left(\mathrm{m}^{2} / \mathrm{s}\right)$. From the $\sigma_{\mathrm{T}}$ distribution in Figure 2, $\rho=1025 \mathrm{~kg} / \mathrm{m}^{3}, \rho_{0}=1022 \mathrm{~kg} / \mathrm{m}^{3}, \mathrm{D}=7.5 \mathrm{~m}$ and $v=1.59 \times 10^{-6} \mathrm{~m}^{2} / \mathrm{s}$ for salinity $31 \%$ and water temperature $4{ }^{\circ} \mathrm{C}$ were given to Equations (12) and (13). Then, if $\mathrm{U}=0.01-0.1 \mathrm{~m} / \mathrm{s}, \mathrm{F}_{\mathrm{d}}=0.067-0.67$ and $\mathrm{R}_{\mathrm{e}}=4.7 \times 10^{4}-4.7 \times 10^{5}$. Thus, the underflow is subcritical and turbulent, indicating relatively low entrainment at the upper boundary [36]. This suggests that the underflow flows down in a relatively long travel distance. This dynamic condition is similar to that of the density underflow in Figure 3 [29], where $F_{d}=0.017-0.17$ and $R_{e}=5.7 \times 10^{4}-5.7 \times 10^{5}$ at $\mathrm{U}=0.01-0.1 \mathrm{~m} / \mathrm{s}, \rho=1025 \mathrm{~kg} / \mathrm{m}^{3}, \rho_{0}=1020 \mathrm{~kg} / \mathrm{m}^{3}, \mathrm{D}=7.5 \mathrm{~m}$, and $v=1.32 \times 10^{-6} \mathrm{~m}^{2} / \mathrm{s}$ for salinity at $25 \%$ and water temperature at $10.6^{\circ} \mathrm{C}$. Thus, dynamic condition of the underflow appears to be consistent over a distance of ca. $100 \mathrm{~km}$ since its initiation in the mixing zone.

In order to know the Coriolis effect on behaviors of the whole Yukon River surface plume, Kelvin number $\mathrm{K}$ for the sediment plume was calculated by the following [37,38]:

$$
\mathrm{K}=\mathrm{W} / \mathrm{Rd},
$$

where $\mathrm{W}$ is the plume width (m), and $\mathrm{R}_{\mathrm{d}}$ is the baroclinic Rossby radius of deformation (m) as follows:

$$
\mathrm{R}_{\mathrm{d}}=\left(\mathrm{g}^{\prime} \mathrm{H}\right)^{1 / 2} / \mathrm{f},
$$

where $\mathrm{H}$ is the water depth $(\mathrm{m})$ at a lift-off point into a surface plume, $\mathrm{f}$ is the Coriolis parameter $(=2 \omega \sin \phi), \omega$ is the earth's rotation rate $\left(=7.29 \times 10^{-5} \mathrm{rad} / \mathrm{s}\right)$, and $\phi$ is the latitude. Here, using the observational result in Figure. $2, \mathrm{H}=11 \mathrm{~m}$ (thermocline depth), $\rho_{0}=1025$ $\mathrm{kg} / \mathrm{m}^{3}, \rho=1020 \mathrm{~kg} / \mathrm{m}^{3}$, and $\phi=63.50^{\circ}$ give $\mathrm{f}=1.30 \times 10^{-4} \mathrm{rad} / \mathrm{s}$ and $R_{d}=5.56 \times 10^{3} \mathrm{~m}$. The location of the liftoff point at the thermocline depth in the coastal region was presumed by extrapolating the bottom slope at the B50 - B53 line. The plume width $W \sim 100 \mathrm{~km}$ is given at the liftoff point from the RGB images in Figure $1 \mathbf{b}$. Thus, $\mathrm{K}=1.8 \times 10$ was obtained, which indicates that the flow has the large scale on which the plume length far exceeds the width and that the flow dynamics is linear [37].

\subsection{Behaviors of Surface Sediment Plume from the Image Analysis}

Figure 8 shows relations between the surface plume area and (a) 21-day mean discharge or (b) 21-day mean sediment load at site PLS, given in Table 1. The correlation is not so high at $\mathrm{R}^{2}=0.3610$ and 0.3676 for the discharge and sediment load, respectively. The low correlation suggests that the suspended sediment dispersion in the plume is not controlled by such mean discharge and sediment load.

Figure 9 shows temporal variations of the plume area and daily mean discharge and daily mean sediment load at site PLS in 2007-2009. Here, the plume area values for the satellite images at AKDT in Table $\mathbf{1}$ are plotted. Although data plots of the plume area are sporadic because of the limited number of the clear satellite images, the plume area appears to respond more strongly to the daily mean sediment load than the daily mean discharge. Especially the high response to the sediment load is seen in the great variation of plume area in July - September 2008, and in the similar plume areas in July and September 2009, which correspond to the temporal variation of sediment load rather than that of discharge. Thus, the suspended sediment dispersion in the plume is probably dominated by relatively large sediment load recorded in a short time period. The shipboard observations at all the eight sites took more $24 \mathrm{hrs}$ (ca. $30 \mathrm{hrs}$ in 2007 and ca. $28 \mathrm{hrs}$ 

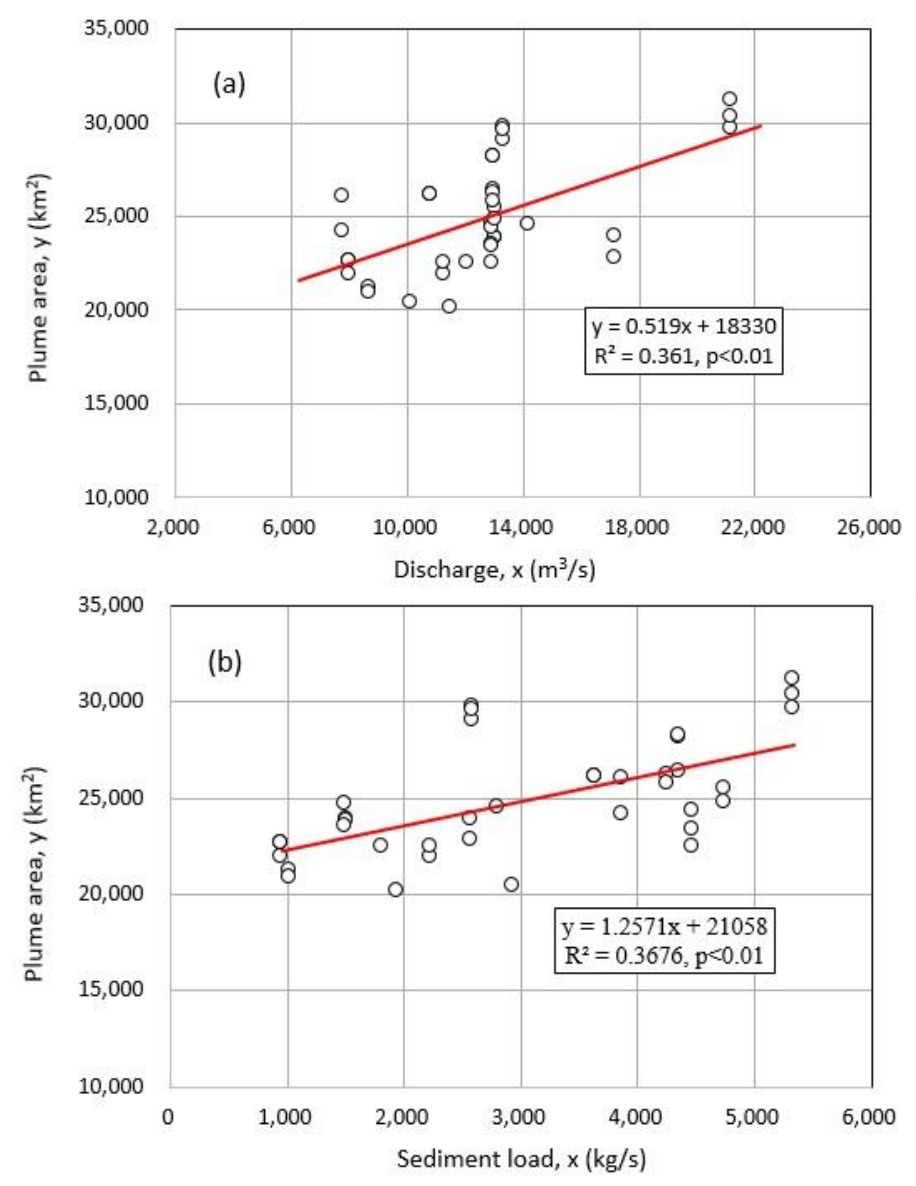

Figure 8. Relations between the plume area and (a) 21-day mean discharge or (b) 21-day mean sediment load at site PLS, given in Table 1.

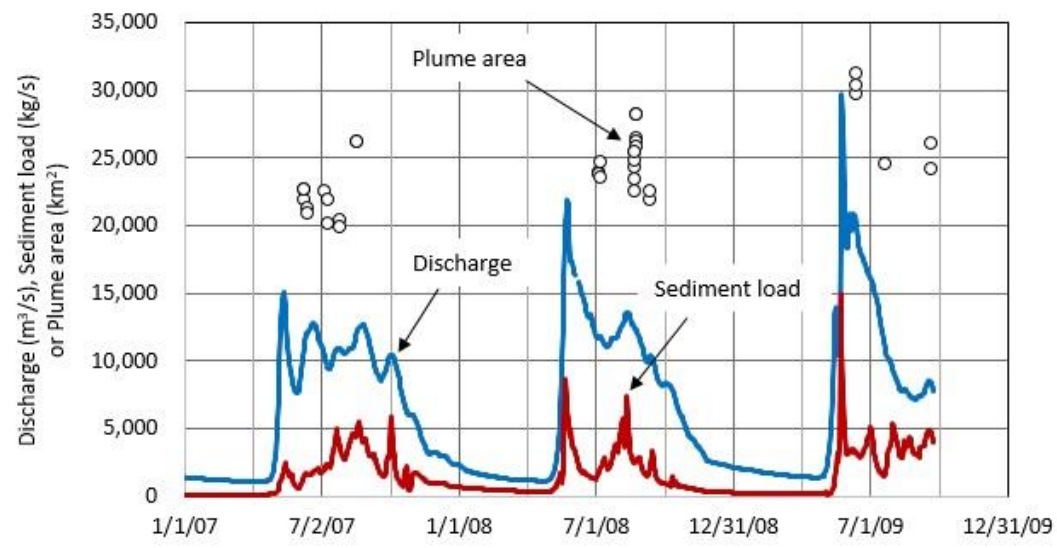

Figure 9. Temporal variations of plume area, daily mean discharge and daily mean sediment load at site PLS in 2007- 2009.

in 2008). Hence, 2-day mean values of discharge and sediment load at site PLS were applied for investigating relations between the plume area and hydrological conditions of the Yukon River. Here, by changing the time lag between the plume area date and the dates of 2-day mean discharge or 2-day mean sediment load, it was explored how the plume area responds to the discharge and sediment load. 

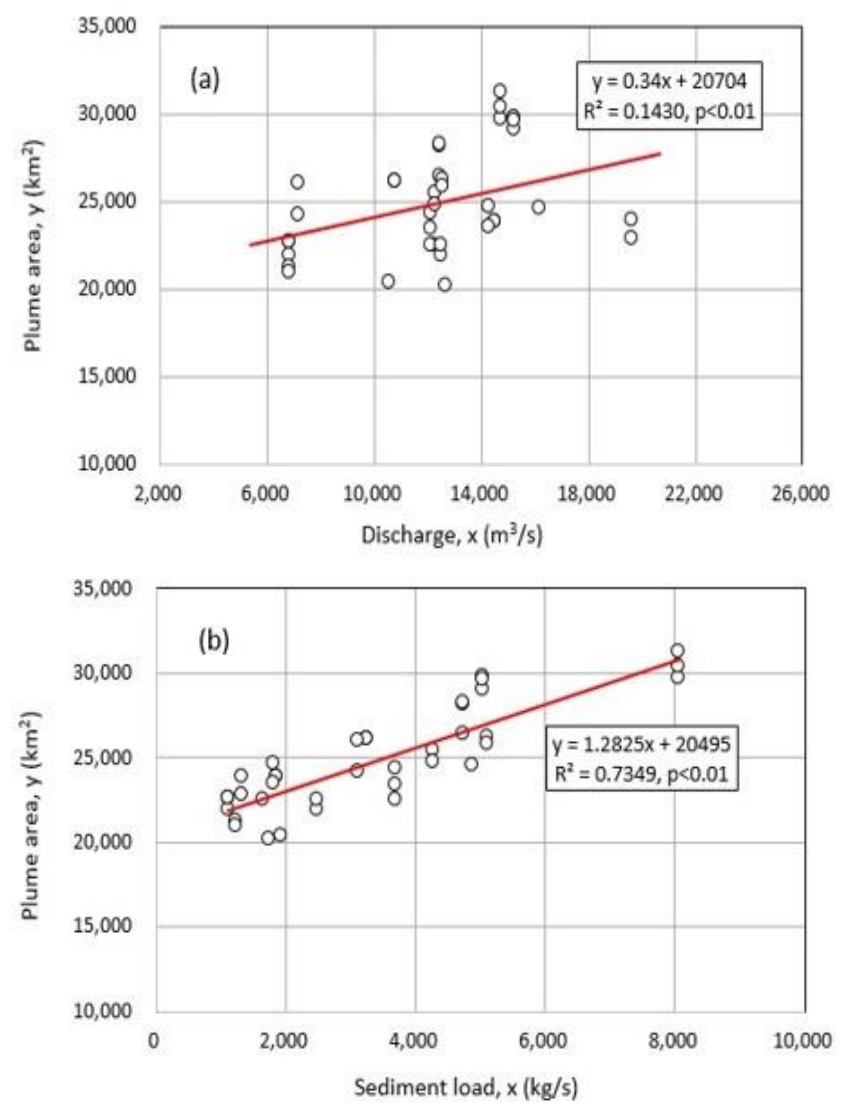

Figure 10. Relations between the plume area and (a) discharge or (b) sediment load averaged for the two days delayed by 20 days and 21 days to the image dates.

Figure 10 shows relations between the plume area and (a) discharge or (b) sediment load averaged for the two days delayed by 20 and 21 days to the image dates. There is a very significant correlation $\left(\mathrm{R}^{2}=0.7349, \mathrm{p}<0.01\right)$ with the sediment load. The correlation with the discharge was not consistently significant $\left(\mathrm{R}^{2}=0.3581\right.$ at maximum in case of lag times of 17 and 18 days) ( $\mathrm{R}^{2}=0.1430$ in Figure 10a). Hence, the dispersion of suspended sediment in the Yukon River plume appears to be controlled by sediment runoff events of the Yukon River (Figure 9), which is initiated mainly by glacier melt in mountainous regions in June - August [26,27]. Nelson and Creager [20] pointed out that sedimentation by the Yukon sediment plume is affected by the strong circulation of northward "Alaskan Coastal Water". However, the high correlation between the plume area and the Yukon sediment load suggests that the dispersion of the whole sediment plume is dominated by the sediment runoff events in the Yukon River.

Here, the influence of wind-driven currents on the northwestward dispersion of the surface sediment plume was explored. If the southeast wind is stronger than the northwest wind during the dispersion, the plume area could increase by the net southeast wind speed. Figure $\mathbf{1 1}$ shows relations between the plume area and the net southeast wind (positive) speed averaged over 20 days from each date of satellite images at (a) Nome and (b) site EMK (Figure 1a). If the net wind speed is positive, the southeast wind is stronger than northwest wind, thus probably increasing the plume area. The net wind speed in Figure $\mathbf{1 1}$ is mostly negative, and thus the northwest wind prevails during the dispersion rather than the southeast wind. Also, the correlation is very low at 0.286 or 0.0993 . Hence, the wind-driven currents appears not to affect the northwestward dispersion of the surface sediment plume. 

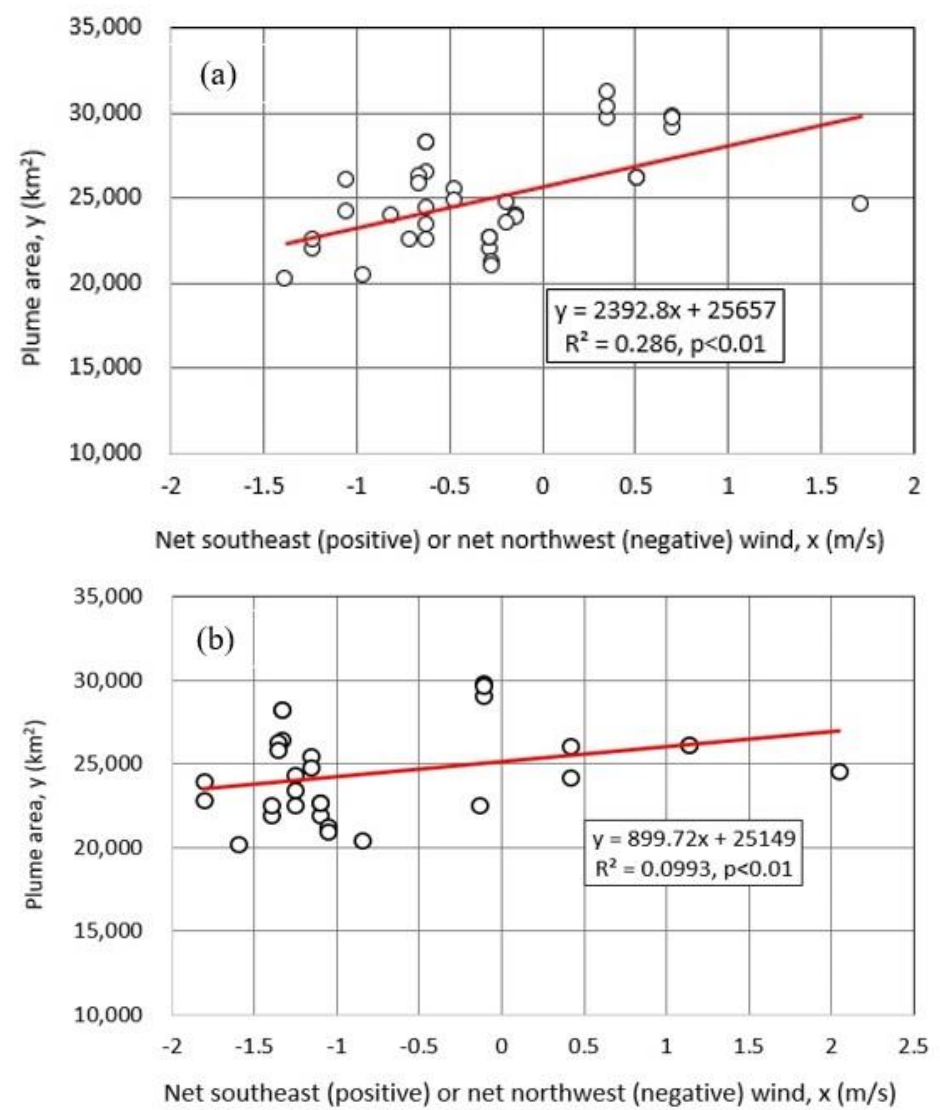

Figure 11. Relations between the plume area and the net southeast wind (positive) or the net northwest wind (negative) averaged over 20 days from each date of satellite images at (a) Nome and (b) site EMK (Figure 1a).

\section{Conclusions}

The shipboard observation for the Yukon River plume in August 2007 revealed that both the surface sediment plume and turbid density underflow occur at the high sediment load of ca. 3,000 kg/s. The density underflow was probably produced through the plunging of turbid water forming the nepheloid (suspended-sediment rich) layer in the coastal mixing zone. The nepheloid layer formation is based on the flocculation of finegrained (more than $90 \%$ silt and clay) suspended sediment from the Yukon River. Meanwhile, in the coastal observation in September 2009, the separation into the surface sediment plume and density underflow in the mixing zone occurred at sediment load of $2.89 \times 10^{3} \mathrm{~kg} / \mathrm{s}$. Hence, the simultaneous occurrence of surface plume and underflow is probably expected at sediment load of more than $2,500 \mathrm{~kg} / \mathrm{s}$.

In the shipboard observation in July 2008, when the sediment load was low at 1,600 $\mathrm{kg} / \mathrm{s}$, the underflow was not observed, and instead, the direct sediment settling from the surface sediment plume prevailed in the lower whole layer. Thus, depending on the magnitude of the river sediment load, the Yukon River plume proved to change the sedimentary process in the offshore region.

The area of the surface sediment plumes at suspended sediment concentration (SSC) of more than $2 \mathrm{mg} / \mathrm{L}$ was numerically obtained by using the three near infrared bands of MODIS/Terra or MODIS/Aqua. There was the significant correlation $\left(\mathrm{R}^{2}=0.7349, \mathrm{p}<0.01\right)$ between the plume area and 2-day mean sediment load delayed by 20 days and 21 days to each date of satellite images. The sediment load with the two time lags reflects the sediment runoff events in the Yukon River. Such runoff events are initiated mainly by the glacier-melt in the glacierized regions of the drainage basin, which could affect the dispersion of the whole surface sediment plume. The wind-driven currents then does not 
appear to influence the northwestward dispersion of the surface sediment plume, since there is no significant correlation between the plume area and the net southeast wind speed.

Author Contributions: K.A.C., T.W. and I.K. participated in the filed surveys to set and manage field instruments; K.A.C. wrote the paper; S.S. participated in the shipboard observations, and conceived and designed the Yukon River-Bering Sea research project; T.H. participated in the shipboard observations; M.T. analyzed all the images of MODIS/Terra or MODIS/Aqua. All authors have read and agreed to the published version of the manuscript.

Funding: This study was financially supported by the Japan Aerospace Exploration Agency (JAXA) as a research in the joint project 2007 and 2008 of IARC/JAXA.

Acknowledgments: We appreciate the official support of Emeritus S. Akasofu, L. Hinzman and Y. Kim, the International Arctic Research Center (IARC), the University of Alaska at Fairbanks (UAF) and the welcome data supply of the U.S. Geological Survey.

Conflicts of Interest: The authors declare no conflict of interest.

\section{References}

1. Branch, R.A.; Horner-Devine, A.R.; Kumar, N.; Poggioli, A.R. River plume liftoff dynamics and surface expressions. Water Res. Res. 2020, 56, 1-24. doi: 10.1029/2019WR026475

2. Guo, X.; Cai, W.-J.; Huang, W.-J.; Wang, Y.; Chen, F.; Murrell, M.C.; Lohrenz, S.E.; Jiang, L.-Q.; Dai, M.; Hartmann, J.; Lin, Q.; Culp, R. Carbon dynamics and community production in the Mississippi River plume. Limnol. Oceanogr. 2012, 57, 1-17. doi:10.4319/lo.2012.57.1.0001

3. Chen, C-C.; Gong, G-C.; Chiang, K-P.; Shiah, F-K.; Chung, C-C.; Hung, C-C. Scaling effects of a eutrophic river plume on organic carbon consumption. Limnol. Oceanogr. 2021, 66, 1867-1881. doi: 10.1002/lno.11729

4. Mulder, T.; Syvitski, J.P.M; Migeon, S.; Faugères, J.-C.; Savoye, B. Marine hyperpycnal flows: initiation, behavior and related deposits. A review. Marine and Petroleum Geology 2003, 20, 861-882. doi:10.1016/j.marpetgeo.2003.01.003

5. Horner-Devine, A.R.; Hetland, R.D.; MacDonald, D.G. Mixing and transport in coastal river plumes. Annu. Rev. Fluid Mech. 2015, 47, 569-594. doi: 10.1146/annurev-fluid-010313-141408

6. Chikita, K.; Yonemitsu, N.; Yoshida, M. Dynamic sedimentation processes in a glacier-fed lake, Peyto Lake, Alberta, Canada. Jpn. J. Limnol. 1991, 52, 27-43. doi: https://doi.org/10.3739/rikusui.52.27

7. Chikita, K.; Sakata, K.; Hino S. Transportation of suspended sediment slowly settling in a caldera lake. Jpn. J. Limnol. 1995, 56, 245-257. doi: https://doi.org/10.3739/rikusui.56.245

8. Schiller, R. V.; Kourafalou, V.H.; Hogan, P.; Walker, N.D. The dynamics of the Mississippi River plume: Impact of topography, wind and offshore forcing on the fate of plume waters. J. Geophys. Res. 2011, 116, C06029. doi:10.1029/2010JC006883

9. Halverson, M.; Pawlowicz, R. Tide, wind, and river forcing of the surface currents in the Fraser River plume. Atmosphere-Ocean 2016, 54, 131-152. doi: 10.1080/07055900.2016.1138927

10. Mulligan, R.P.; Perrie, W.; Solomon, S. Dynamics of the Mackenzie River plume on the inner Beaufort shelf during an open water period in summer. Estuar. Coast. Shelf Sci. 2010, 89, 214-220, doi:10.1016/j.ecss.2010.06.010

11. Gouveia, N.A.; Gherardi, D.F.M.; Aragão, L.E.O.C. The role of the Amazon River plume on the intensification of the hydrological cycle. Geophys. Res. Lett. 2019, 46, 12221-12229. doi.org/10.1029/2019GL084302

12. Masunaga, E.; Fringer, O.B.; Yamazaki, H. An observational and numerical study of river plume dynamics in Otsuchi Bay, Japan. Jour. Oceanogr. 2016, 72, 3-21. doi: 10.1007/s10872-015-0324-2

13. Zavala, C. Hyperpycnal (over density) flows and deposits. Jour. Palaeogeogr. 2020, 9, 17. https://doi.org/10.1186/s42501-02000065-x

14. Lick, W.; Huang, H.; Jepsen, R. Flocculation of fine-grained sediments due to differential settling. Jour. Geophys. Res. : Oceans $1993,98,10,279-10,288$.

15. Strom, K.; Keybani, A. Flocculation in a decaying shear field and its implications for mud removal in near-field river mouth discharges. Jour. Geophys. Res. : Oceans 2015, 121, 2142-2162. doi:10.1002/2015JC011169

16. Milligan, T.G.; Hill, P.S.; Law, B.A. Flocculation and the loss of sediment from the Po River plume. Continental Shelf Res. 2007, 27, 309-321. doi:10.1016/j.csr.2006.11.008

17. Marukussen, T.N.; Elberling, B.; Winter, C.; Andersen, T.J. Flocculated meltwater particles control Arctic land-sea fluxes of labile iron. Scientific Reports 2016, 6, 24033. doi: 10.1038/srep24033

18. Reimers, C.; Carl Friedrichs, C.; Bebout, B.; Howd, P.; Huettel, M.; Jahnke, R.; MacCready, P.; Ruttenberg, K.; Sanford, L.; Trowbridge, J. Coastal benthic exchange dynamics. Skidaway Institute of Oceanography Technical Report TR-04-01 2004, 92pp.

19. Wang, Z.; Li, W.; Zhang, K.; Agrawal, Y.C.; Huang, H. Observations of the distribution and flocculation of suspended particulate matter in the North Yellow Sea cold water mass. Continental Shelf Res. 2020, 204, 104187. https://doi.org/10.1016/j.csr.2020.104187 
20. Nelson, H.; Creager, J.S. Displacement of Yukon-derived sediment from Bering Sea to Chukchi Sea during Holocene time. Geology 1977, 5, 141-146. https://doi.org/10.1130/0091-7613(1977)5<141:DOYSFB>2.0.CO;2

21. Dean, K.G.; McRoy, C.P.; Ahlnäs, K.; Springer, A. The plume of the Yukon River in relation to the oceanography of the Bering Sea. Remote Sensing of Environment 1989, 28, 75-84. https://doi.org/10.1016/0034-4257(89)90106-5

22. Morris, B.A. Seasonality and forcing factors of the Alaskan Coastal Current in the Bering Strait from July 2011 to July 2012 . Master of Science thesis, University of Washington 2019, $82 \mathrm{pp}$.

23. Ortiz, J.D.; Polyak, L.; Grebmeier, J.M.; Darby, D.; Eberl, D.D.; Naidu, S.; Nof, D. Provenance of Holocene sediment on the Chukchi-Alaskan margin based on combined diffuse spectral reflectance and quantitative X-ray diffraction analysis. Glob. Planet. Chang. 2009, 68, 73-84, doi:10.1016/j.gloplacha.2009.03.020

24. Brabets, T.P.; Wang, B.; Meade, R.H. Environmental and hydrologic overview of the Yukon River basin, Alaska and Canada; WaterResources Investigations Report; U. S. Geological Survey: Anchorage, Alaska, USA, 2000; Volume 99-4204, 106 pp., doi: 10.3133/wri994204

25. Striegl, R.G.; Dornblaser, M.M.; Aiken, G.R.; Wickland, K.P.; Raymond, P.A. Carbon export and cycling by the Yukon, Tanana, and Porcupine Rivers, Alaska, 2001-2005. Water Resour. Res. 2007, 43, W02411, doi:10.1029/2006WR005201

26. Chikita, K.A.; Wada, T.; Kudo, I.; Kim, Y. The intra-annual variability of discharge, sediment load and chemical flux from the monitoring: The Yukon River, Alaska. J. Water Resour. Prot. 2012, 4, 173-179, doi:10.4236/jwarp.2012.44020

27. Chikita, K.A.; Wada, T.; Kudo, I. Material-loading processes in the Yukon River basin, Alaska: Observations and modelling. Low Temp. Sci. 2016, 74, 43-54, doi:10.14943/lowtemsci.74.43

28. Milliman, J.D.; Farnsworth, K.L. River Discharge to the Coastal Ocean; Cambridge University Press: Cambridge, UK, 2011; 384 p.

29. Chikita, K. A.; Wada, T.; Kudo, I.; Saitoh, S.; Toratani, M. Effects of river discharge and sediment load on sediment plume behaviors in a coastal region: The Yukon River, Alaska and the Bering Sea. Hydrology 2021, 8, 45. https://doi.org/10.3390/hydrology 8010045

30. Toratani, M.; Ishizaka, J.; Kiyomoto,Y.; Ahn, Y.; Yoo, S.; Kim, S.; Tang, J. Estimation of total suspended matter from three near infrared bands. Proc. of SPIE 2012, 8525, 85250H-1. doi: 10.1117/12.979669

31. Zang, M.; Tang, J.; Dong, Q.; Song, Q.; Ding, J. Retrieval of total suspended matter concentration in the Yellow and East China Seas from MODIS imagery. Remote Sensing of Environment 2010, 114, 392-403. doi:10.1016/j.rse.2009.09.016

32. Wang, Y. H.; Deng, Z. D.; Ma, R. H. Suspended solids concentration estimation in Lake Taihu using field spectra and MODIS data. Acta Scientiae Circumstantiae 2007, 27, 509-515.

33. Doxaran, D.; Froidefond, J-M.; Castaing, P.; Babin, M. Dynamics of the turbidity maximum zone in a macrotidal estuary (the Gironde, France): Observations from field and MODIS satellite data. Estuarine, Coastal and Shelf Science 2009, 81, 321-332. doi: 10.1016/j.ecss.2008.11.013

34. Chikita, K. Sedimentation in an intermountain lake, Lake Okotanpe, Hokkaido. I. Sedimentary processes derived from the grain size distribution of surficial sediments. Jour. J. Limnol. 1986, 17, 53-61. J-GLOBAL ID: 201902016636578161

35. Chikita, K.A.; Smith, N.D.; Yonemitsu, N.; Perez-Arlucea, M. Dynamics of sediment-laden underflows passing over a subaqueous sill: glacier-fed Peyto Lake, Alberta, Canada. Sedimentology 1996, 43, 865-875. https://doi.org/10.1111/j.1365-3091

36. Wells M.; Cenedese, C.; Caulfield, C.P. The Relationship between flux coefficient and entrainment ratio in density currents. Journal of Physical Oceanography 2010, 40, 2713-2727. doi: 10.1175/2010JPO4225.1

37. Seena, G.; Muraleedharan, K.R.; Revichandran, C.; Azeez, S.A.; John, S. Seasonal spreading and transport of buoyant plumes in the shelf off Kochi, Southwest coast of India-A modeling approach. Scientific Reports 2019, 9, 19956. https://doi.org/10.1038/s41598-019-56103-9

38. Cole, K.L.; Hetland, R.D. The effects of rotation and river discharge on net mixing in small-mouth Kelvin number plumes. J. Phys. Oceanogr. 2016, 46, 1421-1436. https://doi.org/10.1175/JPO-D-13-0271.1 